\title{
Tailings co-disposal case study - art or science?
}

\author{
A Beveridge BASF Australia Ltd, Australia \\ P Mutz Murray Zircon Pty Ltd, Australia \\ D Reid Golder Associates Pty Ltd, Australia
}

\begin{abstract}
Murray Zircon Pty Ltd operates the Mindarie Mineral Sands Project in South Australia comprising a mine and concentrator plant. The program for environmental protection and rehabilitation (PEPR) approved by the South Australia Department of Manufacturing, Innovation, Trade, Resources and Energy (DMITRE) requires diligent management of the tailings deposition and overall mine rehabilitation processes.
\end{abstract}

The mining licence was granted based on a maximum permitted operational footprint of the open area of the mine. Mining at Mindarie follows the 'moving-hole' concept whereby topsoil and overburden is removed, ore is mined, tailings are deposited in the mined-out space and are then capped by overburden. The moving hole must advance at approximately $10 \mathrm{~m}$ per day. Consequently, it is imperative that dewatering, consolidation and stabilisation of deposited tailings happens quickly.

Tailings are treated using a high molecular weight polymer which rapidly releases clean water for reuse in the concentrator plant. The polymer binds the coarse and fine particles together to create $a$ non-segregating deposit and accelerates the consolidation rate.

Polymer dosing regimes for the tailings have historically relied on a visual interpretation of the material entering the tailings cells to determine the optimum dose; however, it is the consolidation rate and associated strength gain that determines when overburden replacement can begin. To provide an improved assessment of the impacts of dosage on consolidation, geotechnical testing was undertaken on material treated with different polymer levels.

A recent development for the Mindarie mine is to adjust the natural acidic $\mathrm{pH}$ of tailings to a slightly alkaline level using lime. This was done in order to overcome a throughput bottleneck in the slimes thickener and reduce polymer dosing levels in the slimes thickener and tailings applications. The impact of lime addition on polymer dosing, together with the effect of lime on tailings consolidation properties is also investigated.

\section{Introduction}

The Mindarie heavy mineral sand strandlines mined by Murray Zircon are found within marginal-marine Miocene deposits of the Loxton-Parilla Sands succession. These contain four main lithotypes comprising micaceous clays, silts, silty sands and micaceous sands (Porter 2012). Heavy minerals consisting of zircon, leucoxene, rutile and ilmenite are extracted with typical combined ore grades of around 2.5-5\%. Murray Zircon produces approximately $120,000 \mathrm{t}$ per year of heavy mineral concentrate (HMC) at Mindarie which is exported and separated by others into individual heavy mineral products.

The heavy minerals are extracted from the ore in a primary concentrator plant (PCP). The ore is slurried with water at the mine and pumped to the PCP where it is first de-slimed using hydro-cyclones to remove fine silts and clays and then passed through spiral classifiers to remove the heavy minerals. Following removal of the heavy minerals, the tailings sands are recombined with the slimes that have been thickened to around $45 \% \mathrm{wt} / \mathrm{wt}$, and the combined tailings slurry is pumped back to the mine for treatment with polymer and subsequent disposal. 
Total mine backfill typically consists of seven parts overburden to one part slurried PCP waste (tailings) (PEPR 2011) and in order for mining operations to progress according to schedule, the tailings must be dewatered, consolidated and able to support overburden backfill at an average rate of 10 linear metres per day.

Murray Zircon's Mindarie operations were wet commissioned in December 2012 and achieved steady state in October 2013 (Mutz 2014). At the time of writing, the process has been fully operational for one year.

During the first 18 months of processing, three major problem areas associated with tailings were addressed which have resulted in a doubling of throughput capacity and the evolution of a significantly more cost effective operation together with process results that provide a more scientific approach for future operations.

\section{$1.1 \quad$ Challenges; for art and science}

The challenges, and how they were addressed are discussed in the following section.

Slimes thickener throughput: A major early bottleneck in the process was the slimes thickener which periodically became choked when slimes levels were high. Problems occurred at ore feed rates beyond $250 \mathrm{t} / \mathrm{h}$, despite the application of flocculant doses of more than $2 \mathrm{~kg} / \mathrm{t}$ at the time. The nameplate capacity for the operation is $500-600 t / h$ therefore significant improvement was needed.

Tailings cell design: Tailings were initially deposited in a series of small $100 \mathrm{~m}$ long tailings cells contiguous across the bottom of the mine, in a manner similar to previous operations at this site (by Australian Zircon between the years 2007-2009). Building and operating the tailings cells was very labour intensive and the small size meant that they were unforgiving if any processing or polymer application problems led to a period of low dewatering rates. A more efficient method of operation was required.

Tailings end of line polymer dosing strategy: Tailings cells dosing was based on a visual interpretation of the structure of polymer treated tailings at the point of deposition, however it is the longer term consolidation properties that define the minimum dose needed for effective and efficient 'moving hole' operation. Should dosing strategy be changed to meet the consolidation needs?

\section{Impact of lime on thickener and tailings performance}

\subsection{Methodology}

The choking caused by high slimes levels in the thickener was addressed through hardware changes (modifying the feedwell), ore blending at the mine to deliver more consistent slimes, and the addition of lime slurry to increase $\mathrm{pH}$. Feedwell modifications and a more consistent ore feed took the capacity from around $250 \mathrm{t} / \mathrm{h}$ up to approximately $400 \mathrm{t} / \mathrm{h}$; however it is the subsequent modification of adding lime to increase throughput capacity further that is the subject of this study.

Bench-scale flocculant settling tests to evaluate the impact of lime addition on thickener performance were conducted using fresh slurry in 500 and $1,000 \mathrm{ml}$ cylinders.

Flocculants were prepared in process water as $0.5 \%$ solutions and once dissolved, diluted to 0.05 or $0.025 \%$ prior to use.

Either slimes thickener feed slurry or desanded PCP feed, was blended with thickener overflow water to give the targeted feedwell solids content. The $\mathrm{pH}$ was adjusted where indicated using slurried lime.

Flocculant was added in either one or two-stage addition followed by a series of plunger strokes to build the floc structure, and settling rates were recorded.

Polymer-enhanced tailings tests were also completed in the laboratory by adding Rheomax ${ }^{\circledR}$ ETD products to a tailings sample and applying planetary mixing or beaker pours to simulate the mixing conditions in the 
tailings dam. Material was slumped and the diameter or the yield stress together with initial release water volumes was measured.

Operationally, lime addition to the PCP circuit at Mindarie was applied by delivering metred streams of lime slurry to both the slimes thickener feed bin and the tailings bin at the PCP and controlling the lime additions based on $\mathrm{pH}$. Polymer addition to the slimes thickener (centre-well) and tailings (end-of-line) were augmented with significant quantities of recycled dilution water to minimise polymer dose.

\subsection{Results and discussion}

The natural $\mathrm{pH}$ of the slurried PCP feed ranges between 3 and 6 and contains a variety of clay minerals including kaolinites and swelling smectites in different proportions and chemistries. The clays are present in the 3-6 $\mu \mathrm{m}$ size range and have dispersant tendencies, thereby resisting settling and dewatering (PEPR 2011).

The combination of variable and constantly changing $\mathrm{pH}$ and clay minerals content of the PCP feed slurry and associated particle dispersion characteristics resulted in poor settling, or no settling when the thickener became overloaded, and $\mathrm{pH}$ modifications were investigated to improve the attraction between particles and provide a more consistent feed source.

Cylinder test results showed lime to have a significant impact on flocculant dose (Figure 1). Informal tests also indicated a similar effect was achieved by using caustic soda; however, no data from those tests are available.

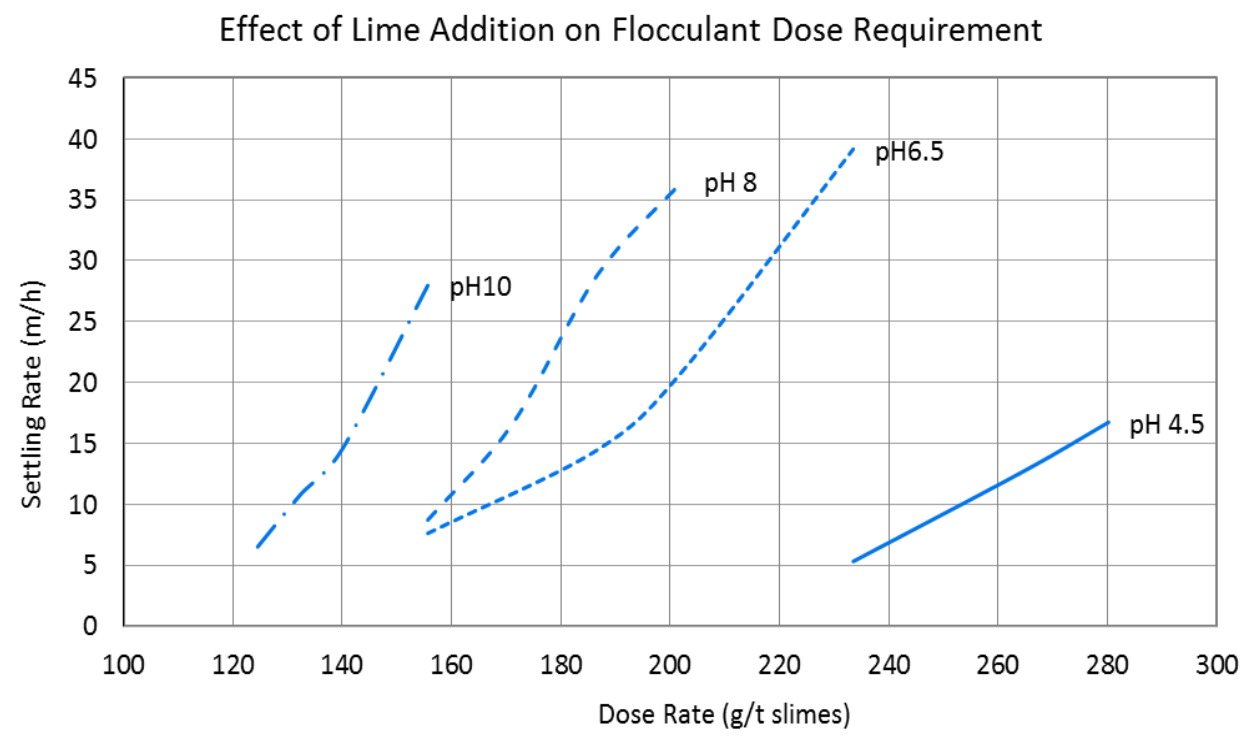

\section{Figure 1 Effect of lime addition on flocculant dose}

For a settling rate of $10 \mathrm{~m} / \mathrm{h}$ the natural $\mathrm{pH}$ material at $\mathrm{pH} 4.5$ required $250 \mathrm{~g} / \mathrm{t}$ of Magnafloc 336 flocculant in laboratory tests, however as the $\mathrm{pH}$ was increased the flocculant requirement reduced significantly to around $160 \mathrm{~g} / \mathrm{t}$ at neutral $\mathrm{pH}$ and $130 \mathrm{~g} / \mathrm{t}$ at $\mathrm{pH} 10$. 
The reduction of flocculant dose with lime addition is a common phenomenon and is due to the coagulation brought about by the addition of calcium. In addition, increasing the $\mathrm{pH}$ of the slimes also helps to keep the flocculant solution fully ionised and able to bridge between particles more easily. If clays within the slurry are reactive there could also be an ion exchange mechanism between the calcium and the sodium resulting in a more stabilised clay surface that is resistant to attrition and more easily flocculated.

Environmental regulations at Mindarie require that tailings are close to neutral $\mathrm{pH}$ when deposited and so the $\mathrm{pH} 10$ modification is for interest only and the significant gains for adjusting the $\mathrm{pH}$ to neutral or slightly above was adopted.

Lime slurry addition to the thickener feed bin, with a caustic polish to neutralise the ore prior to flocculation was implemented from January 2014 , and its effect on full scale production figures is illustrated in Figure 2.

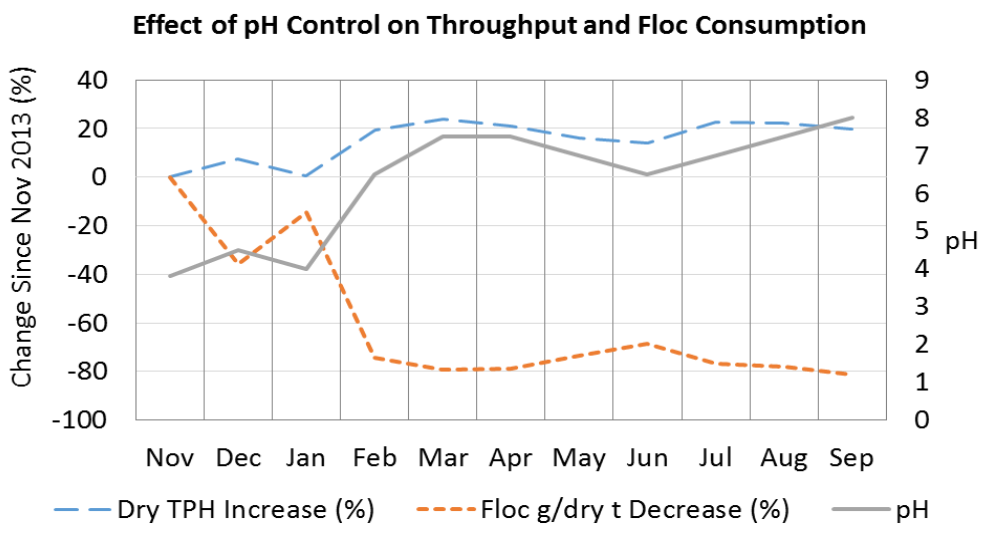

\section{Figure 2 Effect of $\mathrm{pH}$ control on throughput and floc consumption}

Changing the $\mathrm{pH}$ from approximately 4 to 7 during January-February resulted in throughput capacity improvements of around $20 \%$. At the same time flocculant dose dropped by around $75 \%$. Results were steady thereafter, with periods of slightly lower $\mathrm{pH}$ (6.5 compared with 7.5) resulting in less effective performance of both throughput and floc consumption. See June results of Figure 2. The most recent results available show the effect of raising the $\mathrm{pH}$ to 8 which realised even lower flocculant addition rates of around $80 \%$ less than the original dose, but no additional increase in throughput for the short time since implementation.

Work is ongoing to find a combination of the optimum coagulating conditions (for example lime, or other options) and $\mathrm{pH}$, coupled with the optimum flocculation conditions to increase throughputs and costs still further.

\subsection{Polymer treated tailings}

The lime addition in the thickener also had a downstream effect on the Rheomax ETD polymer treatment at the tailings cells. Tailings at Mindarie consist of underflow from the slimes thickener described above, combined with a secondary stream of sand reject from the spirals. Typical tailings comprise approximately $45 \%$ wt/wt slurry and have a large particle size differential. An analysis by the Department of Primary Industries Soil Conservation Service laboratories from July 2014 is shown in Table 1.

\section{Table 1 Analysis of Mindarie tailings}

\begin{tabular}{lccccc}
\hline Sample ID & \multicolumn{5}{c}{ Method: P7B/2 } \\
& Clay & Silt & Fine sand & Coarse sand & Gravel \\
Untreated & 12 & 2 & 50 & 36 & $<1$ \\
\hline
\end{tabular}


Laboratory tests show that the lime or $\mathrm{pH}$ change has a large impact on the polymer dosage needed to achieve a target structure (slump diameter). Figure 3 shows that in the laboratory the dose of Rheomax ${ }^{\circledR}$ ETD 9050 required to reduce a slump diameter to $100 \mathrm{~mm}$ is $230 \mathrm{~g} / \mathrm{t}$ at pH 4, which reduces $28 \%$ to $165 \mathrm{~g} / \mathrm{t}$ at $\mathrm{pH} 8$.

Further improvements were also achieved in this application by introducing polymer in a more dilute form.

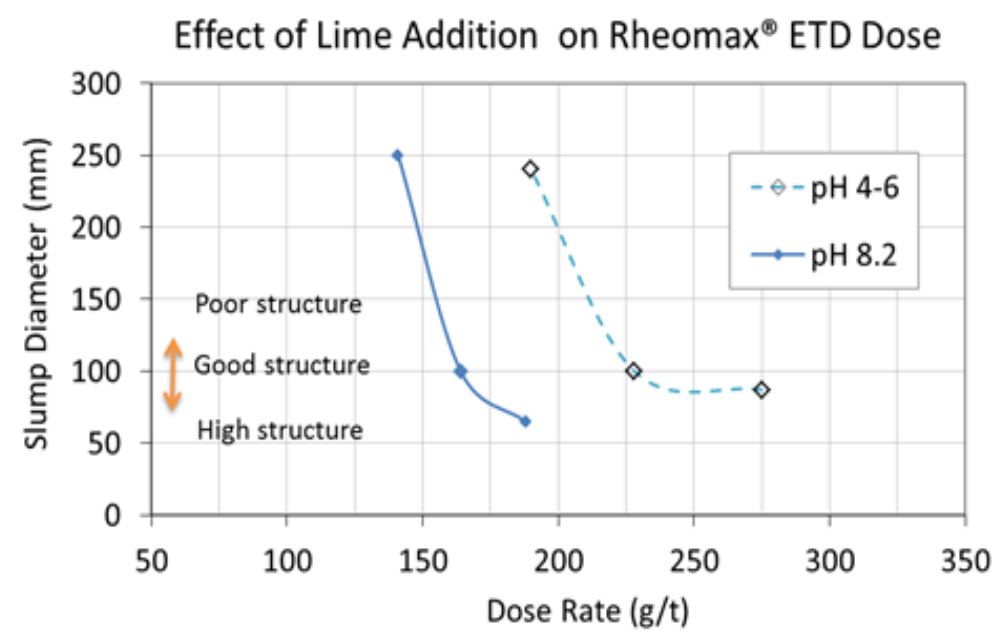

Figure 3 Effect of lime on end-of-pipe polymer dose

Effect of Dilution on Rheomax ${ }^{\circledR}$ ETD Dose

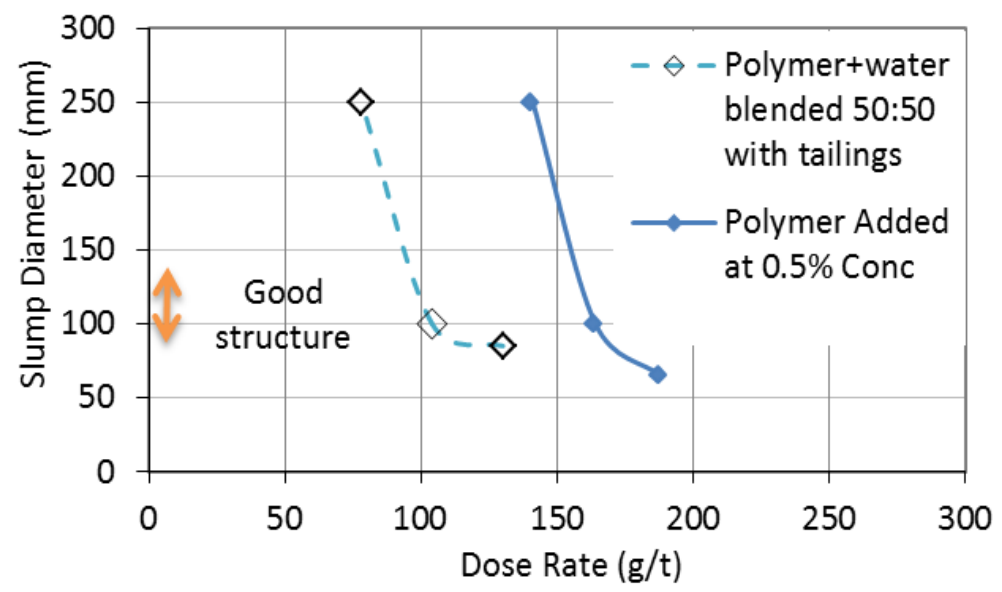

Figure 4 Effect of dilution water on end-of-pipe polymer dose

Figure 4 shows laboratory tests of $0.5 \%$ polymer concentration compared against an application where polymer is added to an equal volume of dilution water to the tailings stream and then blended. This treatment reduces the dose required to achieve the target yield stress from 160 to $100 \mathrm{~g} / \mathrm{t}$ Rheomax ${ }^{\circledR}$ ETD 9050.

In the laboratory, a combination of lime and dilution effects therefore was able to reduce dosing needs at the end-of-pipe from 230 to $100 \mathrm{~g} / \mathrm{t}$.

Both polymer dilution and $\mathrm{pH}$ control was applied to Mindarie's tailings operation. Polymer dilution was applied initially and lime was introduced through a single stream in February to deliver a maximum $\mathrm{pH}$ of around 6. A second lime stream was brought online in June to increase the pH adjustment capability further. Figure 5 shows the impact on polymer consumption. A rise in $\mathrm{pH}$ from 4 to 7.5 translated to a drop in polymer dosage of $50 \%$. 


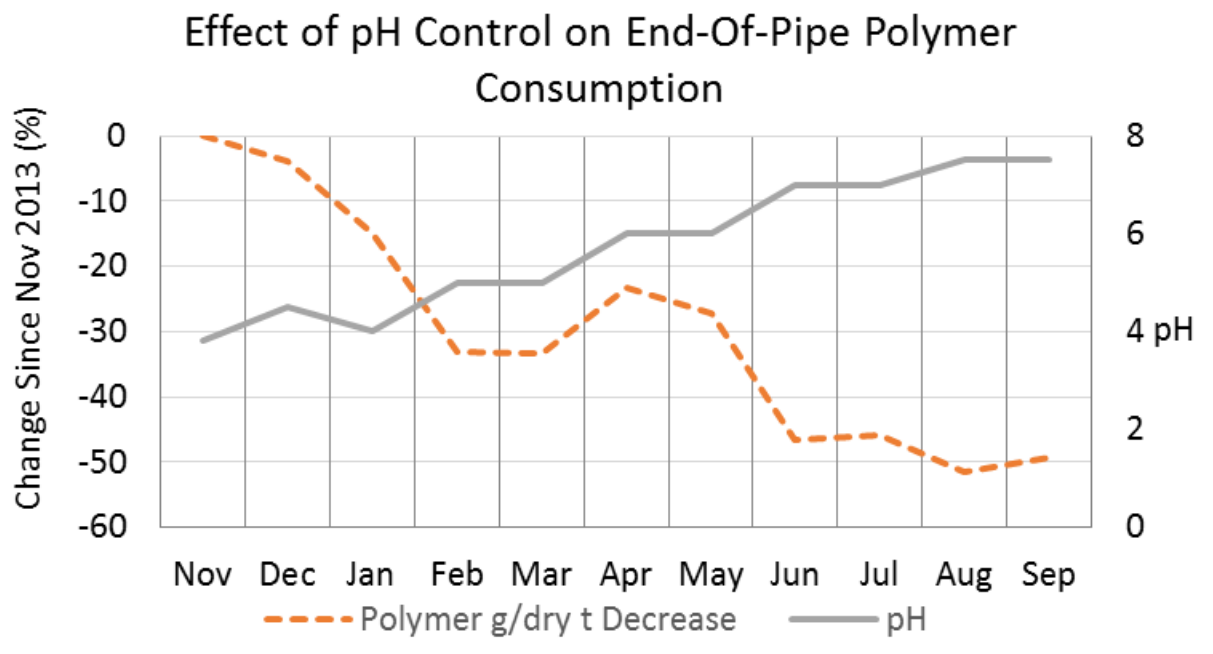

Figure 5 Effect of pH on end-of-pipe polymer dose

\subsection{Art or science?}

Science and chemistry can describe the mechanisms that allows tighter floc particles to form and thus improve the flux and settling rates in this type of application; however operational art (empirical observations and trial and error testing) and the need for innovative solutions were the drivers behind the implementation of lime dosing, the end-of-line polymer dilution system and some of the other modifications that significantly enhanced the performance of slimes thickening and tailings dewatering.

\section{$3 \quad$ Impact of changes to tailings cell design}

\subsection{Methodology}

The tailings management plan employed at Mindarie during the first few months of operation was inherited from the previous operator, and consisted of a chain of small cells, adjacent to each other that followed the mining void.

Cells were filled one at a time, left to achieve a target strength, and the overburden replaced. Several cells were open at any point in time due to the continuous sequence applied to each individual cell, of building, filling, dewatering and rehabilitating the surface. Figure 6 is a schematic of the process.

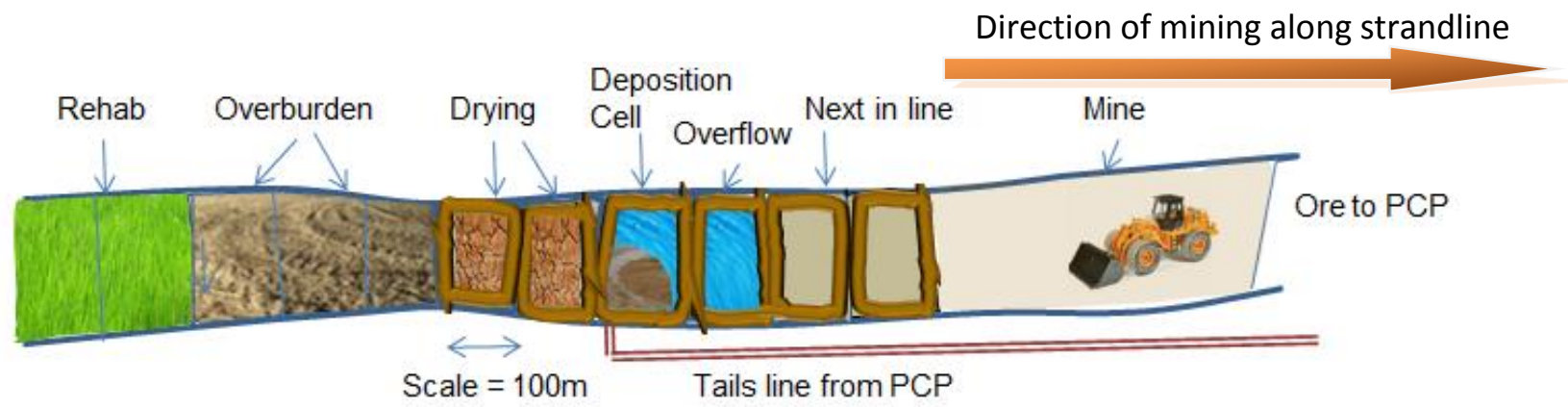

Figure 6 Inherited tailings cell design; plan view

Mining would typically occur 2-3 cells removed from tailings deposition and each cell was covered as soon as the tailings deposit had sufficient yield strength to support the overburden and topsoil. 


\subsubsection{Current tailings cell design}

From October 2013, a new tailings sequencing concept was introduced. Tailings cells must still fit within the strandline and are therefore still approximately $150 \mathrm{~m}$ wide; however, the length was extended from $100 \mathrm{~m}$ to $400 \mathrm{~m}$. Another major change is that cells are no longer adjacent to each other and are positioned along the strandline where the mined void is at its deepest to allow for deeper tailings deposition and minimum aerial footprint. Figure 7 is a profile view illustration of the positioning logic of the tailings cells, and Figure 8 shows a plan view schematic of the current configuration.

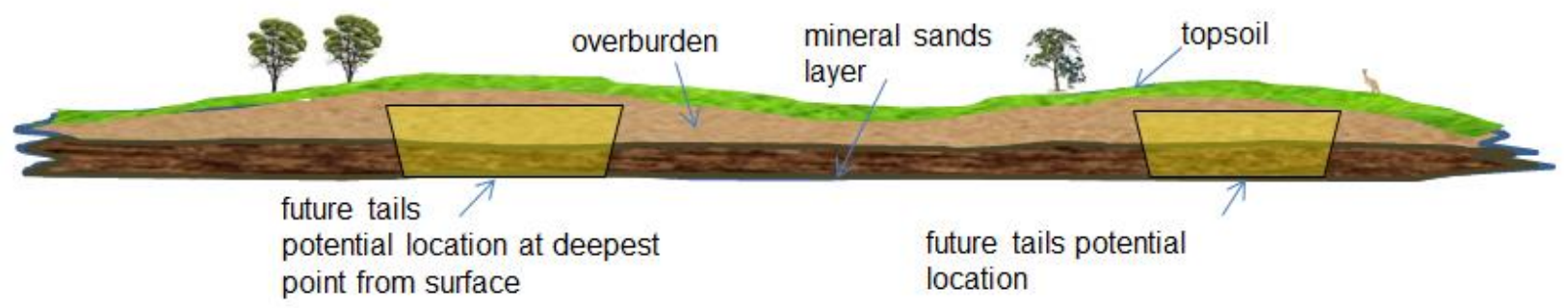

Figure 7 Schematic of location of tailings cells (not to scale); profile view

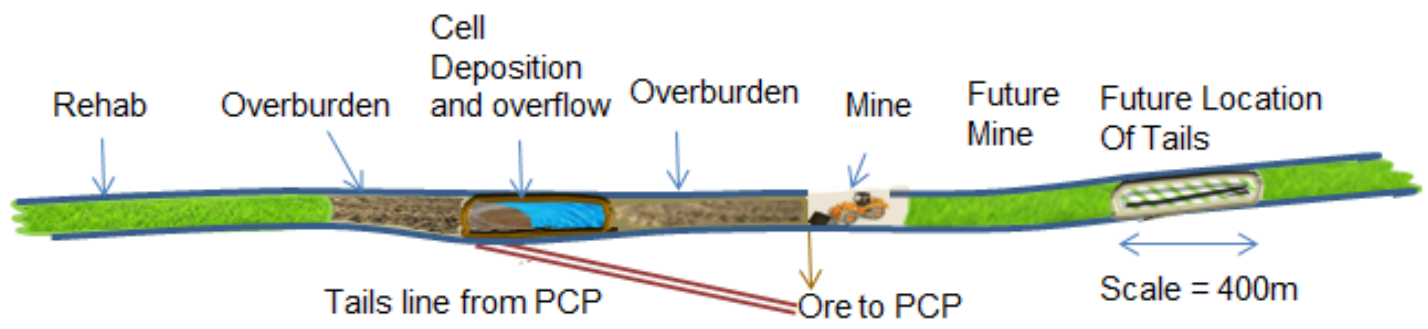

Figure 8 Current tailings configuration; plan view

\subsection{Results and discussion}

Changing from adjacent small tailings cells to strategically placed larger tailings cells has resulted in significant improvements to the cost efficiencies of mining at Mindarie.

The original mine design outlined in the approved program for environmental protection and rehabilitation (PEPR) required that on average each tailings cell is built, filled, dried, and topped with overburden every 10 days so as not to exceed the maximum open area of the mine outlined in the PEPR. Cells were filled with tailings one-by-one where possible, however if slimes levels were unusually high or if the end-of-line polymer dosing was incorrect, then slower dewatering led to an increase in consolidation time and a need to relocate discharge points to the next cell, before returning them to the previous cell to complete the deposition once further dewatering had occurred and sufficient space was available. This process result in significant resource time and machinery costs due to continual wall building and spigot relocation work. It could have also required mining to be slowed or suspended so as not to exceed the maximum open area of the mine per the PEPR.

The new design (Figures 7 and 8) allows one much larger tailings cell to be used for around 5-6 months. Each tailings cell remains positioned along the strandline, but will be located where the original deposit base is deepest below the surface, thereby giving the maximum depth for a given footprint. Mining regulations allow that the thickness of overburden replaced need not be the same as when removed. Therefore a tailings cell located in an area where the heavy mineral seam was located deep under the overburden, could be filled with a deeper layer of tailings and a thinner layer of overburden. Table 2 illustrates the differences in time and wall building needs in transitioning from the old cell design to the new. 
Table 2 Cell capacities comparison

\begin{tabular}{ccccccc}
\hline & $\begin{array}{c}\text { Width } \\
(\mathbf{m})\end{array}$ & $\begin{array}{c}\text { Length } \\
(\mathbf{m})\end{array}$ & $\begin{array}{c}\text { Height } \\
\mathbf{( m )}\end{array}$ & $\begin{array}{c}\text { Average } \\
\text { capacity } \\
\left.\mathbf{( m}^{\mathbf{3}}\right)\end{array}$ & $\begin{array}{c}\text { Time available } \\
\text { for filling with } \\
\text { tails }\end{array}$ & $\begin{array}{c}\text { Tailings cell wall build } \\
\text { per } 1 \text { km strandline } \\
\text { (linear metre) }\end{array}$ \\
\hline $\begin{array}{c}\text { Original } \\
\text { design (1-15) }\end{array}$ & 150 & 100 & 3.6 & 54,000 & $9-10$ days & $11 \times 150 \mathrm{~m}$ \\
New design & 150 & 400 & 15 & 900,000 & $160-170$ days & $<2 \times 150 \mathrm{~m}$ \\
\hline
\end{tabular}

\subsection{Art or science?}

Driven primarily by economic pressures, the decision to modify the tailings cell design can retrospectively be shown to be born out of a healthy mix of both operational art and science. This is true from the initial concept stage, through testing and implementation and continues with each process improvement. This is to say science and engineering principles were used to test conceptual ideas and evaluate test results. However, as the initial concepts originated from queries and observations of operational personnel, and continues to be refined based on day to day operational experience, the overall credit for the success of the new tailings cell design is awarded to art.

\section{$4 \quad$ End-of-line polymer dosing strategy}

Changes in both the $\mathrm{pH}$ of the tailings and the cell design have an impact on the geotechnical properties of the tailings. It was not known what impact the addition of lime would have on the consolidation rates over the timescale required for rehabilitation. Similarly, it was not known what impact the change in polymer dosing levels would have on consolidation rates. Other questions were whether dosing polymer to a visual consistency based on instant water release was appropriate for either of the cell designs, or would a lower dose be sufficient given the timescale needed for dewatering.

Testwork was conducted by Golder Associates Pty Ltd (Golder) to determine the most effective polymer treatment at Mindarie.

\subsection{Methodology}

It is known that significant alteration of the properties of the Mindarie slimes occurs when slurried samples are left for a period of time and then testwork is conducted. This has a large impact on both flocculant dose and end-of-pipe polymer dose. For this reason, fresh slurry was treated on site by applying targeted doses of Rheomax ${ }^{\circledR}$ ETD 9050 to achieve the required responses. Water was allowed to run off each test for a period of 30 minutes and then samples were shipped to Golder's Perth laboratory for further testing. Rheomax ${ }^{\circledR}$ ETD 9050 was chosen for these tests since it had previously been selected as the most effective product for Mindarie tailings at the new $\mathrm{pH}$ adjusted levels.

The following evaluations were undertaken:

- General classification testing.

- Undrained settling tests of untreated material.

- Consolidometer tests (Sheeran \& Krizek 1971) with and without lime, and at different polymer levels.

- Flexible wall permeameter tests.

- Consolidation modelling to assess polymer dosage effect on post depositional tails behaviour was also undertaken. 
The samples that were subjected to testing and modelling were:

- Feed to PCP at natural pH of 4.4.

- Feed to PCP with lime added to pH 8.5.

- $\mathrm{pH} 8.4$ tailings with low dose Rheomax ${ }^{\circledR}$ ETD 9050 (115 g/t).

- $p H 8.4$ tailings with medium dose Rheomax ${ }^{\circledR}$ ETD 9050 (150 g/t).

- pH 8.4 tailings with high dose Rheomax ${ }^{\circledR}$ ETD 9050 (200 g/t).

\subsection{Results and discussion}

\subsubsection{Effect of lime on tailings consolidation}

Feed to the PCP at pH 4.4 was sampled prior to any chemical addition (lime or polymer), and a portion of this was then $\mathrm{pH}$ adjusted using lime slurry to $\mathrm{pH} 8.5$ to give the lime-effect comparison tests.

Settling tests results show that lime has a short-term negative impact on both density and permeability, reducing dry density by $13 \%$ and also reducing inferred permeability (Table 3 ).

Table 3 Effect of lime on dry density and inferred permeability

\begin{tabular}{ccc}
\hline Sample & Dry density at 17 days & Inferred permeability* $(\mathrm{m} / \mathbf{s})$ \\
\hline PCP feed & 0.91 & $1.6 \times 10^{-7}$ \\
PCP feed with lime & 0.79 & $2.4 \times 10^{-8}$ \\
\hline
\end{tabular}

*Inferred from initial settling rate using method proposed by Takada and Mikasa (1986)

Subsequent consolidation testing to simulate longer term conditions in the cell however indicated that there is no significant difference between the two samples when loading is applied, with void ratios, coefficients of consolidation and permeability tests giving similar results to each other (Figures 9-11).

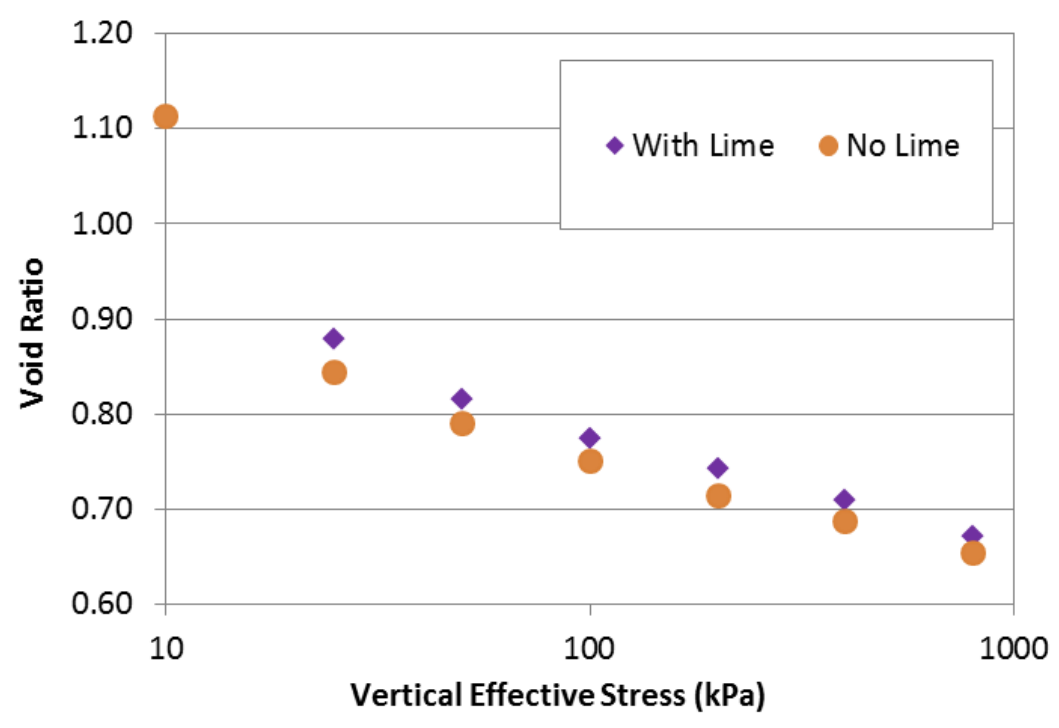

Figure 9 Effect of lime on void ratio 


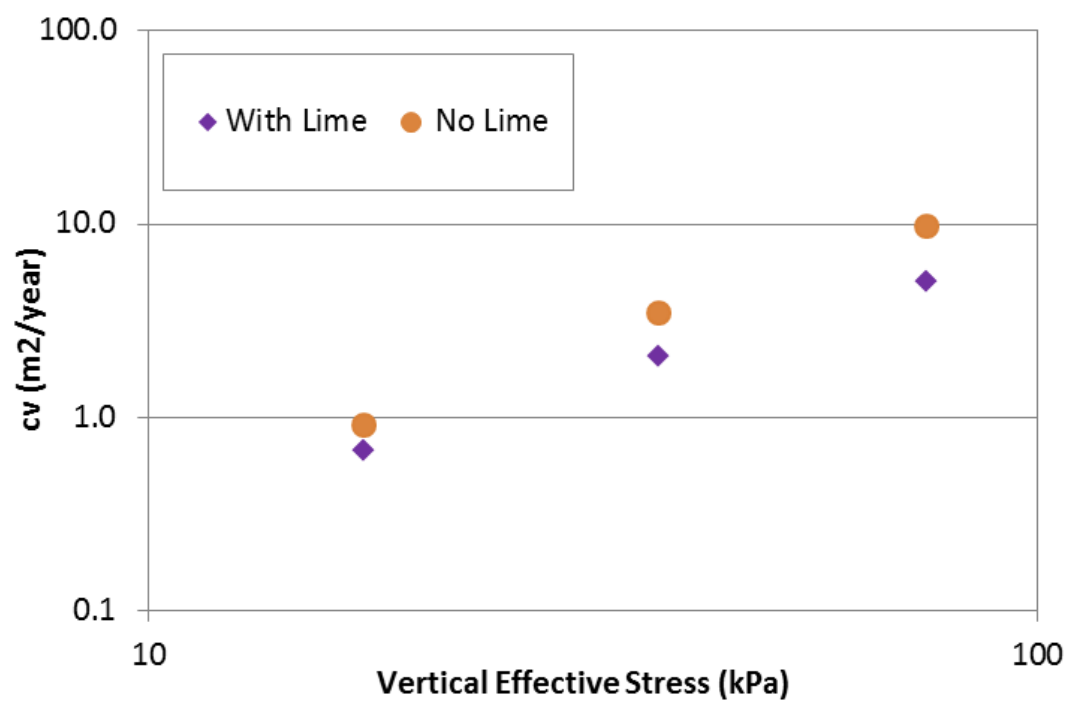

Figure 10 Effect of lime on coefficient of consolidation

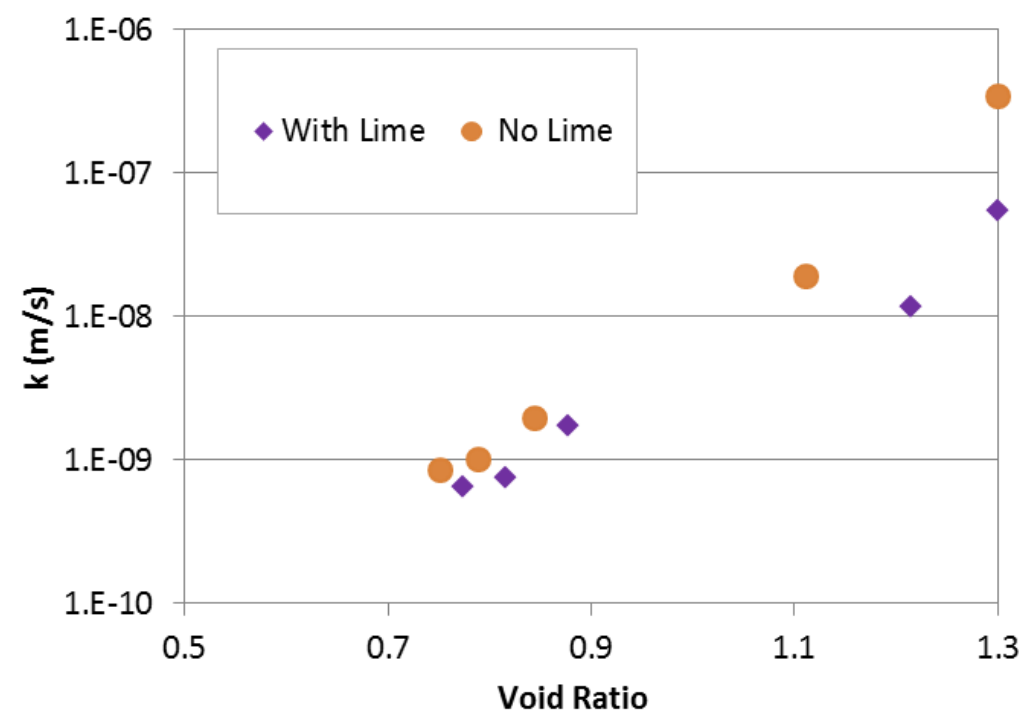

\section{Figure 11 Effect of lime on permeability}

For each of these soil properties, the variation seen between the two samples are within the likely range of accuracy for consolidation testing.

These results suggest that lime can be applied to the tailings at the current levels without any significant effect on longer term material consolidation properties and therefore rehabilitation times.

\subsubsection{Effect of polymer dose on tailings consolidation}

The effect of end-of-pipe polymer treatment on tailings consolidation was evaluated by first treating Mindarie tailings that had had lime treatment, with varying doses of Rheomax ${ }^{\circledR}$ ETD 9050 and allowing the release water to discharge, as it would in the tailings pond.

The range of doses selected represented a range of visual effects (Figures 12(a-d)). The lowest dose at 115 $\mathrm{g} / \mathrm{t}$ produced a weak structure that did not appear to capture all the slimes, and sheared easily thereby releasing more fines into the run-off water (Figure 12(b)). The middle dose at $150 \mathrm{~g} / \mathrm{t}$ produced a tighter structure and captured the fines, but could be broken down with prolonged mixing (Figure 12(c)). The high dose produced a strong shear resistant structure that captured all fines (Figure 12(d)). 


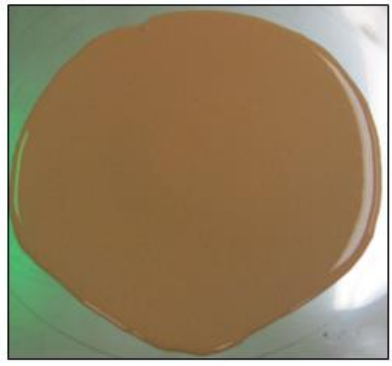

(a)

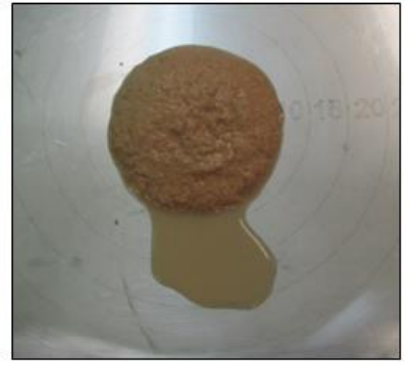

(b)

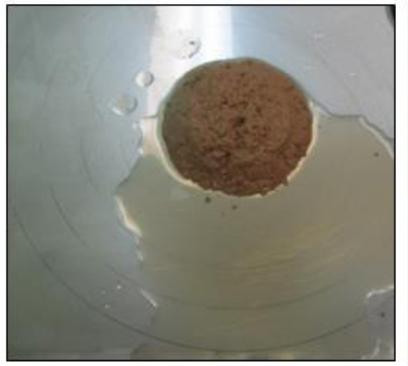

(c)

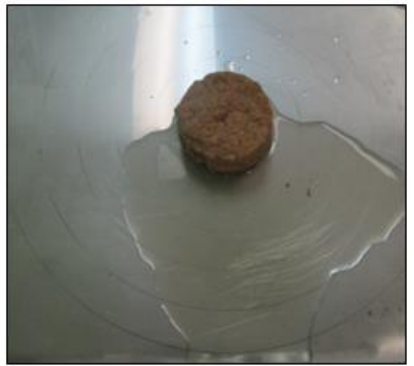

(d)

Figure 12 Relative structure and water quality of blank; (a) $0 \mathrm{~g} / \mathrm{t}$; (b) $115 \mathrm{~g} / \mathrm{t}$; (c) $150 \mathrm{~g} / \mathrm{t}$; (d) $200 \mathrm{~g} / \mathrm{t}$

Wet sieving tests were conducted on the dewatered tails samples received by Golder (Table 4).

Table 4 Fines content of tailings after Rheomax ${ }^{\circledR}$ ETD 9050 treatment

\begin{tabular}{ccccc}
\hline Sample & No polymer & $\begin{array}{c}\text { Low dose } \\
(\mathbf{1 1 5} \mathbf{g} / \mathbf{t})\end{array}$ & $\begin{array}{c}\text { Medium dose } \\
\mathbf{( 1 5 0} \mathbf{g} / \mathbf{t})\end{array}$ & $\begin{array}{c}\text { High dose } \\
(\mathbf{2 0 0} \mathbf{g} / \mathbf{t})\end{array}$ \\
\hline Slimes (passing 38 $\mu$ ) & $13.6 \%$ & $10.1 \%$ & $12.0 \%$ & $13.3 \%$ \\
\hline
\end{tabular}

Results showed that the lowest dosed sample had a significantly lower slimes content than the other samples, with only $10.1 \%$ passing $38 \mu \mathrm{m}$ compared with $13-14 \%$ for the untreated and highest dose material. The middle-dosed sample had $12 \%$ pass $38 \mu \mathrm{m}$. Since all tests were from the same initial bulk sample, this (in addition to the visual evidence) also implies that the low-dosage sample did not adequately capture all the fines within the polymer matrix, or that fines were captured initially but insufficient polymer bonds allowed them to be sheared away with further mixing, resulting in $26 \%$ of the total fines being lost into the run-off water. The middle-dosed sample lost around $11 \%$ of the total fines content and this is on the border of experimental error of the wet-sieving method, although visually it seems probable that a small amount of fines from this sample were also lost into the runoff.

Un-loaded, undrained, dry density results of the polymer treated samples showed that Rheomax ${ }^{\circledR}$ ETD 9050 created an immediate and significant effect within the dosage range evaluated. Polymer treated samples gave density increases of between $55-58 \% \mathrm{wt} / \mathrm{wt}$ almost instantaneously, whereas the untreated sample took around one month to achieve comparable density.

Consolidation testing showed that similar void ratio results were obtained for all samples when effective stress was higher than $25 \mathrm{kPa}$, whether treated with polymer or not. The effect of polymer on consolidation coefficient and permeability however induced very substantial changes in permeability that were approximately two orders of magnitude above that of the untreated ore (Figures 13 and 14). 


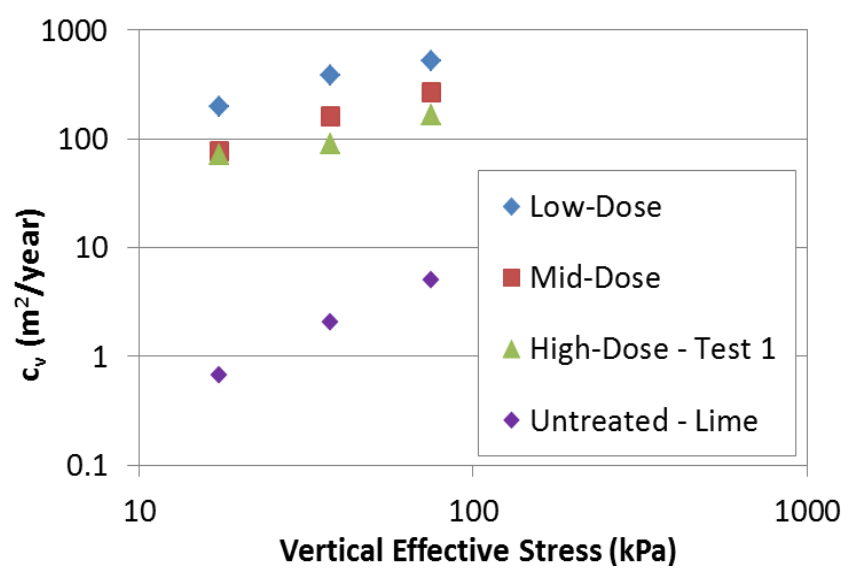

Figure 13 Effect of Rheomax ${ }^{\circledR}$ ETD 9050 on coefficient of consolidation

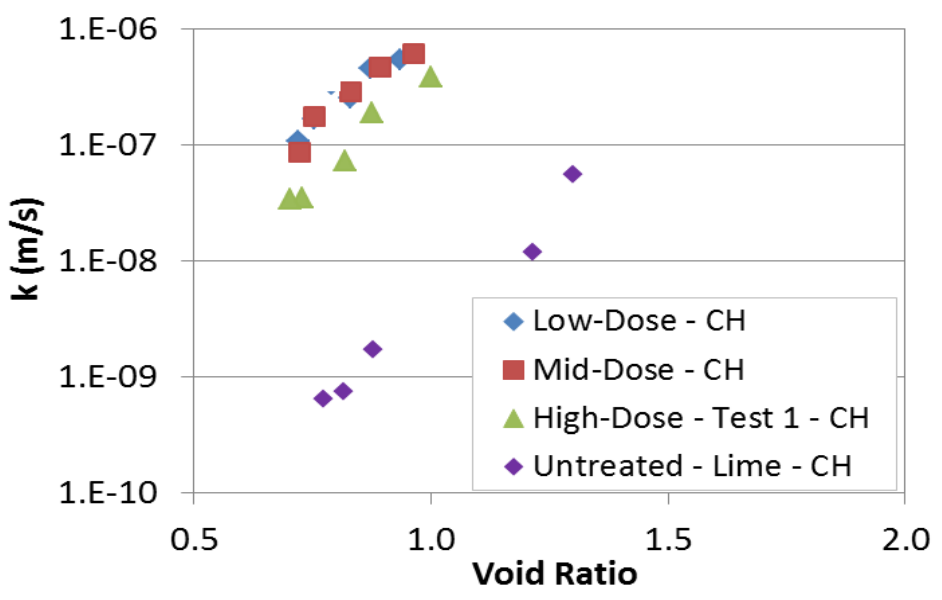

Figure 14 Effect of Rheomax ${ }^{\circledR}$ ETD 9050 on permeability

It is noted that significant changes to permeability and rate of consolidation of tailings as a result of polymer treatment has been reported elsewhere, e.g. Jeeravipoolvarin et al. $(2009,2010)$, and Azam (2011). The changes observed in the responses of Mindarie tailings however were larger than the authors have observed in similar test programs, and larger than most published examples in the literature. Owing to these factors, some additional testing was undertaken in an attempt to confirm the results obtained. While the changes seen in this study are greater than those typically observed, the authors are unaware of any published examples of the effects of polymer treatment on a gap-graded material such as the Mindarie tailings. This gap-grading may make the material more susceptible to significant fabric realignments following polymer treatment.

First, an additional consolidation test was undertaken on the high dose sample, which provided indistinguishable results from the original high dose test. Further consideration of the results and test protocol lead to the hypothesis that the macro-scale fabric resulting from polymer treatment might lead to preferential pathways through the material. Such macro-scale fabric within the slurry consolidometer would be, in some ways, be representative of material after deposition. However, when adjacent to the rigid sidewalls of the slurry consolidometer column, it is not known if such a fabric would result in unrepresentative pathways for flow. To assess this, additional constant head tests were undertaken within a triaxial cell. As differential pressures within the cell hold the membrane in close contact to the tailings, edge effects such as those hypothesised to be occurring within the slurry consolidometer would be less likely. The flexible wall permeability tests produced very similar results to the consolidation testing however, indicating that edge-effects within the slurry consolidometer did not significantly affect the testing. 
A final possibility investigated was that segregation of the untreated material, resulting in a low-permeability layer of fines at the top of the slurry consolidometer cell, was influencing the results. To assess this, the untreated sample, after testing and oven drying, was cut into top and bottom portions, and particle-size distributions determined for each. The top and bottom samples were seen to have indistinguishable particle-size distributions. This suggests that segregation with the consolidation test did not occur and can therefore not explain the lower rate of consolidation and permeability for the untreated sample.

The coefficient of consolidation and permeability results indicated that the lowest dose of Rheomax ${ }^{\circledR}$ ETD 9050 applied has the most beneficial effect (in terms of rate of consolidation increase), followed by the mid and high dose conditions (Figure 13). This is counter-intuitive based on visual observations of the structure, however it is likely that the behaviours of the low dose (and possibly the mid dose) samples are being influenced by the coarser gradation, i.e. loss of fines, from these tests.

Overall, the results suggest that polymer addition has a substantial beneficial effect on degree of consolidation under low stress conditions. From the numbers obtained, the middle dose may be the most desirable from an operations point of view, giving high consolidation and permeability whilst retaining the majority of the fines fraction within the sample and not allowing dirty recirculating water to be a problem for process water pond management or for the PCP. The highest dose also satisfies all technical requirements, but would of course be less cost-effective than any lower dosing levels.

\subsubsection{Consolidation modelling}

Consolidation modelling was undertaken to assess the implications of varying polymer dosing levels and of different cell geometries at Mindarie. As the width of tailings cells is based on the width of the strandlines $(\sim 150 \mathrm{~m})$ this cannot be varied, however the length of tailings cell used is more flexible. On this basis, consolidation models were developed with cell lengths of both 400 and $600 \mathrm{~m}$ (Scenario A and B, respectively), to assess how different geometry could affect rehabilitation advance rate. An additional model was developed for, to simulate historic conditions when the deposition rates were lower and cell sizes smaller. It is noted from Section 3 above that historically, tailings cells were continuous along the strandline, whereas currently a given $1.5 \mathrm{~km}$ of strandline would generally include one $400 \mathrm{~m}$ long tailings cell, therefore, rehabilitation rates for a given length of strandline are controlled by the progress of consolidation within the intermittently spaced tailings cells.

Table 5 Rate of rise calculation

\begin{tabular}{|c|c|c|c|c|}
\hline Parameter & Unit & $\begin{array}{l}\text { Scenario A } \\
\text { current cell }\end{array}$ & $\begin{array}{c}\text { Scenario B } \\
\text { alternative cell }\end{array}$ & $\begin{array}{l}\text { Scenario C } \\
\text { historic cell }\end{array}$ \\
\hline Tailings type & - & Polymer-treated & Polymer-treated & $\begin{array}{l}\text { Polymer- } \\
\text { treated }\end{array}$ \\
\hline Cell width & $\mathrm{m}$ & 150 & 150 & 150 \\
\hline Tailings cell length & $\mathrm{m}$ & 400 & 600 & 100 \\
\hline $\begin{array}{c}\text { Strandline lengths } \\
\text { between tailings } \\
\text { cells }\end{array}$ & $\mathrm{m}$ & 1,100 & 1,650 & 0 \\
\hline $\begin{array}{l}\text { Cell average } \\
\text { effective depth* }\end{array}$ & $\mathrm{m}$ & 15 & 15 & 3.5 \\
\hline Plan area & $\mathrm{m}^{2}$ & 60,000 & 90,000 & 15,000 \\
\hline Deposition rate & $\mathrm{m}^{3} /$ hour & 650 & 650 & 400 \\
\hline
\end{tabular}




\begin{tabular}{|c|c|c|c|c|}
\hline Parameter & Unit & $\begin{array}{l}\text { Scenario A } \\
\text { current cell }\end{array}$ & $\begin{array}{c}\text { Scenario B } \\
\text { alternative cell }\end{array}$ & $\begin{array}{r}\text { Scenario C } \\
\text { historic cell }\end{array}$ \\
\hline $\begin{array}{l}\text { Deposition percent } \\
\text { solids }\end{array}$ & $\%$ by mass & 50 & 50 & 50 \\
\hline Deposition rate & t/hour & 470 & 470 & 290 \\
\hline Settled density & $t / m^{3}$ & 0.97 & 0.97 & 0.97 \\
\hline $\begin{array}{l}\text { Depositional } \\
\text { rate of rise }\end{array}$ & $\begin{array}{c}\mathrm{m}^{3} / \mathrm{m}^{2} / \text { day } \\
\text { (m/day) }\end{array}$ & 0.19 & 0.13 & 0.24 \\
\hline
\end{tabular}

*Estimated based on freeboard allowances and approximate beach slopes

Consolidation models were developed with the one dimensional finite strain code CONDESO (Yao \& Znidarcic 1997). Finite strain models enable many of the salient features of tailings consolidation to be simulated, including incremental deposition, significant variation in material parameters with stress, and the relatively large displacements typical to self-consolidation of slurries.

Tailings were incrementally placed in the model, based on the estimated depositional rate of rise. This represents the average increase in depth of tailings in an idealised column of material, on the basis of cell area, deposition rate, and settled dry density. Tailings material parameters were based on average values of the three polymer treated materials.

To assess the effects of different cell lengths on rehabilitation rate, consolidation models were run until the level of tailings reached the maximum depth relevant to the scenario under consideration. It was assumed that deposition would cease at this point, and the tailings would continue to consolidate. Post-deposition settlement was monitored until it reached a rate less than $1.8 \mathrm{~m} / \mathrm{year}$, which represents the average evaporation rate. The average evaporation rate has been used in the current study to enable general comparisons between different scenarios. It has been proposed (Seneviratne et al. 1996) that when the rate of water reporting to the surface of a tailings deposit becomes less than the evaporation rate, air drying will begin to induce suctions in the upper layers of material. This will eventually result in a trafficable surface, enabling rehabilitation to commence. Therefore, surface settlement becoming less than $1.8 \mathrm{~m} /$ year provided a criterion to allow comparison of the effects of different depositional strategies on the commencement of rehabilitation.

The results of the modelling undertaken are summarised in Table 6 and Figure 15.

Table 6 Effect of deposition variables on consolidation time

\begin{tabular}{ccccc}
\hline Measure & Unit & $\begin{array}{c}\text { Scenario A } \\
\text { current deposition rate } \\
\mathbf{4 0 0} \mathbf{m} \text { cell length }\end{array}$ & $\begin{array}{c}\text { Scenario B } \\
\text { potential deposition } \\
\text { rate }-\mathbf{6 0 0} \mathbf{m} \text { cell } \\
\text { length }\end{array}$ & $\begin{array}{c}\text { Scenario C } \\
\text { historic deposition } \\
\text { rate }-\mathbf{1 0 0 ~} \mathbf{m} \text { cell } \\
\text { length }\end{array}$ \\
\hline $\begin{array}{c}\text { Polymer dose } \\
\text { Filling time }\end{array}$ & $\begin{array}{c}\mathrm{g} / \mathrm{t} \\
\text { days }\end{array}$ & $150-200$ & $150-200$ & $150-200$ \\
$\begin{array}{c}\text { Volume deposited } \\
\text { Time for evaporative } \\
\text { consolidation to } \\
\text { commence }\end{array}$ & $\mathrm{m}^{3}$ & 411 & 163 & 9 \\
$\begin{array}{c}\text { Post-depositional } \\
\text { settlement }\end{array}$ & $\mathrm{m}$ & 130 & 97,800 & 3,600 \\
\hline
\end{tabular}




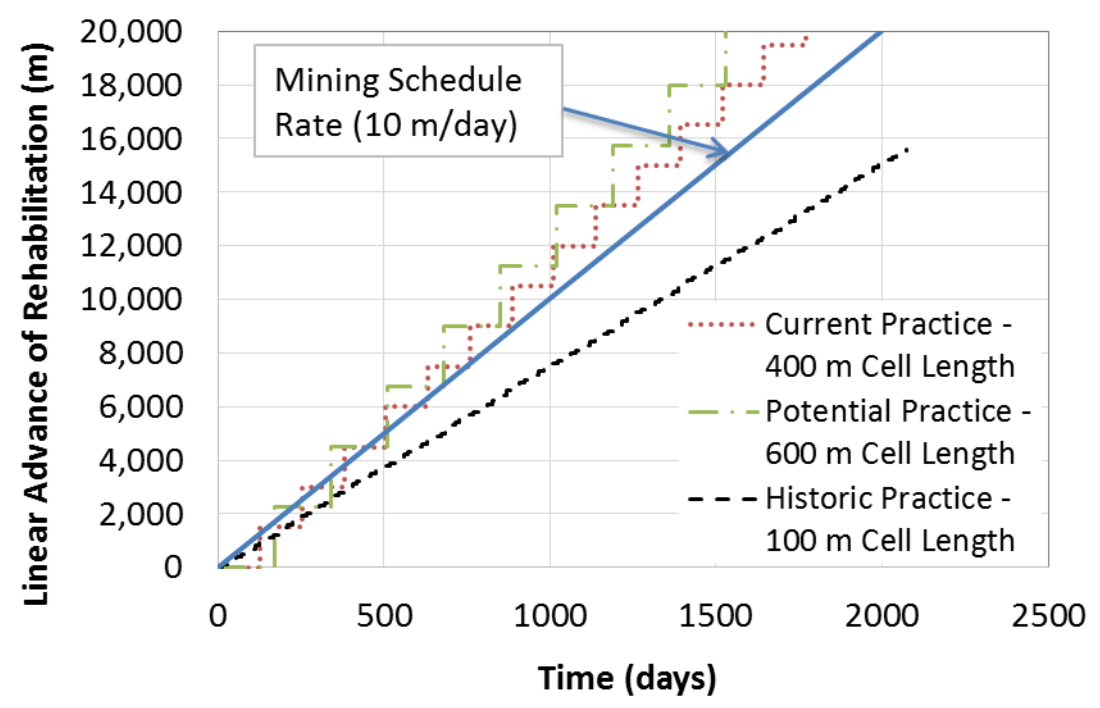

\section{Figure 15 Rehabilitation rate}

The calculations indicate that the rehabilitation rates outpace the mining schedule rates when tailings are treated using the current practice (i.e. $650 \mathrm{~m}^{3} / \mathrm{h}$ deposition rate, $150-200 \mathrm{~g} / \mathrm{t}$ polymer dose and $400 \mathrm{~m}$ long cells with $15 \mathrm{~m}$ depth). This means that sufficient time is available for tailings consolidation and that cell rehabilitation is able to keep pace with the mining scheduling rates. If a sufficient space within the strandline allows it, even longer tailings dams (e.g. $600 \mathrm{~m}$ ) may allow even faster rehabilitation rates than has been previously possible, thereby ensuring that this aspect of the process is not a bottleneck to future increased mining advance rates. The historic cells by comparison would not be able to keep pace with current mining schedule, chiefly due to their lower depths $(3.5 \mathrm{~m})$, and fall behind the mining schedule (Figure 15).

Not only has the current cell arrangement delivered improved rehabilitation rates, it also allows much more efficient operating costs for Mindarie as a result of the reduced civil works associated with less wall building and less frequent spigot repositioning.

\subsection{Art or science?}

Consolidation modelling of tailings deposition in this context suffers a number of limitations that must be acknowledged. Many of these are a result of the limitations of current state of consolidation modelling representivity. Some of these limitations, and their implications, are outlined as follows:

- The idealised columns of tailings modelled, which provide an 'average' representation of filling rates within a cell, do not capture two or three-dimensional effects. In particular, it is unlikely that the tailings will fill a $600 \mathrm{~m}$ by $150 \mathrm{~m}$ cell in a uniform manner, with tailings added at a uniform rate throughout the cell. Rather, cycling of deposition will be required for operational reasons.

- Were a two or three-dimensional consolidation model to be applied, in order for it to significantly improve the predictive capabilities of the modelling exercise, the two or three-dimensional model would need to include filling at differential rates owing to cycling of deposition, and possibly the onset of air drying during fallow periods. This level of modelling detail is impractical in the context of the study undertaken.

- Tailings forms a sloped beach, and the material near the perimeter of the cell will shed surficial water to the lower portions of the deposited tailings. This will influence the ability of air drying processes to occur at different parts of the beach.

- Shearing of the polymer treated samples may further influence their behaviour. This has been noted by Jeeravipoolvarn et al. (2010). 
- The commencement of air drying was based on the time at which settlement reduced to less than a rate of $1.8 \mathrm{~m} /$ year, which represents the average evaporation rate for site. Capturing the full effects of evaporation on tailings consolidation, including desaturation, rewetting, and three-dimensional effects is somewhat outside of typical current engineering practice.

Science has provided analytical techniques to assess the consolidation behaviour of deposited tailings, at least in a one dimensional context. However, the application of such models requires operational art to assess their applicability in the context of a study of the kind outlined herein.

\section{$5 \quad$ Conclusions}

The addition of lime to take $\mathrm{pH}$ up from 4 to 8 has changed the properties of mineral sands slimes and given a $20 \%$ increase in thickener throughput capacity and an $80 \%$ reduction in flocculant dosing rate to the feedwell.

The downstream consequences of the $\mathrm{pH}$ change was to reduce end-of-pipe polymer dosing requirement by $50 \%$.

Lime addition to tailings has a slightly negative impact on short term settling rates, but no significant effect on longer term consolidation and is unlikely to affect rehabilitation times at Mindarie.

Redesigning the configuration of tailings cells at Mindarie has meant that for every linear kilometre of strandline, only $300 \mathrm{~m}$ of retaining walls are required instead of $1.6 \mathrm{~km}$ of walls. Each cell is also allowed 5-6 months rehabilitation time in order to keep pace with the mining plan, instead of 10 days. These changes have led to significant civil and manpower cost reductions.

End-of-pipe polymer addition over a large range of dosages has a significant beneficial effect on initial dewatering rates and longer term consolidation rates. Each dosage rates tested allow consolidation of the tailings at the rate needed to match the targeted rate of mining both for 100 and $400 \mathrm{~m}$ long cells. Extending the cell even further to $600 \mathrm{~m}$ has a small further improvement to rehabilitation times.

The lowest polymer doses involved samples that had already lost a proportion of the fines content to runoff water. Such doses would in practice leave a legacy of recirculating fines. The mid-range dosage $(150 \mathrm{~g} / \mathrm{t})$ is therefore the most effective.

\section{Acknowledgement}

Thank you to everyone at Murray Zircon Mindarie who have welcomed all technical testing to assist with the understanding of the extensive processing changes made, and have truly lived by the words on their company logo of 'knowledge:innovation:excellence'.

\section{References}

Azam, S 2011, 'Large strain behaviour of polymer-amended laterite slurries', International Journal of Geomechanics, vol. 11, no. 2, pp. 105-112.

Jeeravipoolvarn, S, Scott, JD \& Chalaturnyk, RJ 2009, 'Geotechnical characteristics of laboratory in-line thickened oil sands tailings', Proceedings of the Thirteenth International Conference on Tailings and Mine Waste.

Jeeravipoolvarn, S, Scott, JD \& Chalaturnyk, RJ 2010, 'Composite tailings made from in-line thickened oil sands tailings', Proceedings of the 2nd International Oil Sands Conference, pp. 337-347.

Mutz, P 2014, Mindarie Mineral Sands Project: a new beginning, AUSIMM, Carlton, viewed 1 October 2014, www.ausimm.com.au /content/docs/branch/2014/adelaide_2014_04_presentation_P.Mutz.pdf

PEPR 2011, Mindarie Mineral Sands Project Mindarie C and A2, Marine Innovation Southern Australia, viewed 1 October 2014, www.misa.net.au/_data/assets/pdf_file/0004/170995/PEPR_main_text.pdf

Porter, TM 2012, Mindarie, Porter GeoConsultancy Pty Ltd, Adelaide, viewed 1 October 2014, www.portergeo.com.au/database

Seneviratne, NH, Fahey, M, Newson, TA \& Fujiyasu, Y 1996, 'Numerical modelling of consolidation and evaporation of slurried mine tailings', International Journal for Numerical and Analytical Methods in Geomechanics, vol. 20, no. 9, pp. 647-671.

Sheeran, DE \& Krizek, RJ 1971, 'Preparation of homogeneous soils samples by slurry consolidation', Journal of Materials, vol. 6, no. 2 , pp. 356-373. 
Takada, N \& Mikasa, M 1986, 'Determination of consolidation parameters by selfweight consolidation test in centrifuge', in RN Yong \& FC Townsend (eds), Proceedings of Consolidation of Soils: Testing and Evaluation, American Society for Testing and Materials, Fort Lauderdale, pp. 548-566.

Yao, D \& Znidarcic, D 1997, Crust formation and desiccation characteristics for phosphatic clays: user's manual for computer program CONDESO, Florida Institute of Phosphate Research, Polk Country. 